\title{
Risk factors for Toxoplasma gondii and Neospora caninum seropositivity in buffaloes in Paraiba State, Brazil
}

\author{
Fatores de risco associados à soropositividade para Toxoplasma gondii e Neospora caninum \\ em búfalos no Estado da Paraíba, Nordeste do Brasil
}

\begin{abstract}
Arthur Willian de Lima Brasil ${ }^{1}$; Roberta Nunes Parentoni ${ }^{1}$; Thais Ferreira Feitosa ${ }^{1}$; Camila de Sousa Bezerra ${ }^{2}$; Vinicius Longo Ribeiro Vilela ${ }^{1}$; Hilda Fátima de Jesus Pena ${ }^{3}$; Sergio Santos de Azevedo ${ }^{1 *}$
\end{abstract}

\begin{abstract}
${ }^{1}$ Programa de Pós-Graduaçáo em Medicina Veterinária, Universidade Federal de Campina Grande - UFCG, Patos, PB, Brasil
${ }^{2}$ Curso de Graduaçăo em Medicina Veterinária, Universidade Federal de Campina Grande - UFCG, Patos, PB, Brasil

${ }^{3}$ Laboratório de Doenças Parasitárias, Faculdade de Medicina Veterinária e Zootecnia, Universidade de São Paulo - USP,

São Paulo, SP, Brasil
\end{abstract}

Received February 8, 2015

Accepted April 15, 2015

\begin{abstract}
The aims of this survey were to determine the frequency of anti-Toxoplasma gondii and anti-Neospora caninum antibodies and to identify the risk factors associated with seropositivity among buffaloes in the state of Paraíba, Brazil. This survey included 136 buffaloes belonging to 14 herds. To detect anti- $T$. gondii and anti- $N$. caninum antibodies, the indirect fluorescent antibody test (IFAT) was used. Among the 136 samples analyzed, 17 (12.5\%) were positive for anti-T. gondii antibodies with titers ranging from 64 to 1,024 , and $26(19.1 \%)$ for anti- $N$. caninum with titers from 200 to 1,600. Animals seropositive for both T. gondii and N. caninum were found in 10 of the 14 herds (71.4\%). Semi-intensive management systems (odds ratio $=2.99$ ) and presence of pigs (odds ratio $=4.33$ ) were identified as risk factors for T. gondii and N. caninum, respectively. It can be suggested that T. gondii and $N$. caninum are widespread in buffaloes in Paraíba, and that additional surveys are needed in order to ascertain the importance of these agents for this species and for pigs, and the influence of the farming type on occurrences of seropositive animals.
\end{abstract}

Keywords: Toxoplasmosis, neosporosis, bubaline, seroepidemiology, control.

\section{Resumo}

Os objetivos deste trabalho foram determinar a frequência de anticorpos anti-Toxoplasma gondii e anti-Neospora caninum e identificar os fatores de risco associados com as soropositividades em búfalos do Estado da Paraíba, Brasil. Foram utilizados 136 búfalos oriundos de 14 propriedades. Para a detecçấo de anticorpos anti-T. gondii e anti- $N$. caninum, foi empregada a reaçấo de imunofluorescência indireta (RIFI). Das 136 amostras analisadas, 17 (12,5\%) foram positivas para anticorpos anti-T. gondii, com títulos variando de 64 a 1.024; e $26(19,1 \%)$ para anticorpos anti- $N$. caninum, com títulos de 200 a 1.600. Das 14 propriedades, em $10(71,4 \%)$ houve animais soropositivos tanto para $T$. gondii como para $N$. caninum. O manejo semi-intensivo (odds ratio $=2,99$ ) e a presença de suínos (odds ratio $=4,33$ ) foram identificados como fatores de risco para T. gondii e N. caninum, respectivamente. Sugere-se que T. gondii e N. caninum estão disseminados em búfalos do Estado da Paraíba, bem como a necessidade de mais estudos acerca da importância desses agentes nessa espécie e em suínos, e da influência do tipo de criação na ocorrência de animais soropositivos.

Palavras-chave: Toxoplasmose, neosporose, bubalinos, soroepidemiologia, controle.

\section{Introduction}

Buffaloes are known for their rusticity, tolerance and resistance to infectious and parasitic diseases, and are better adapted than cattle to adverse environmental conditions. Because they are versatile

\footnotetext{
*Corresponding author: Sérgio Santos de Azevedo. Laboratório de Doenças Transmissíveis, Centro de Saúde e Tecnologia Rural, Universidade Federal de Campina Grande - UFCG, Av. Universitária, s/n, Santa Cecília, CEP 58700970, Patos, PB, Brasil. e-mail: sergio@vps.fmvz.usp.br
}

animals, they have become an excellent alternative for livestock farming in Brazil, since they have triple aptitude (milk production, meat production and traction), in addition to their easy adaptability to hostile environments, such as flood-prone lands, coastal areas, mountains and plains (NARDI, 2005).

Currently, Brazil has a prominent position within buffalo-rearing and has a headcount of more than a million animals, of which 
the Northeastern region accounts for around 122,000 animals. In the state of Paraiba, the buffalo headcount totals approximately 933 animals (IBGE, 2012).

Increasing productivity and technification of buffalo-rearing has favored introduction of infectious and parasitic diseases into the herds, as a result of changes in management, increased animal density and confinement. Toxoplasma gondii and Neospora caninum have not yet been shown to be important causative agents of abortions among buffaloes, but this possibility cannot be discarded. Investigations on the implications of these agents in relation to reproductive losses in this species are needed (GONDIM et al., 2007).

$T$. gondii and $N$. caninum are two morphologically related protozoa that present cosmopolitan geographical distribution. Both species may infect a broad range of animal species, including buffaloes. They have life cycles in which the definitive hosts are carnivore species and both of them cause abortions and congenital diseases in ruminants (DUBEY et al., 1988; DUBEY, 2003). Recent studies on occurrences of anti- $T$. gondii antibodies in buffaloes in Brazil have revealed rates ranging from $1.1 \%$ to 49.9\% (SILVA et al., 2010; SOUZA et al., 2001). For N. caninum, high frequencies of antibodies in buffaloes were found in studies in the north (40.9\%) (SILVA et al., 2010), southeast (64\%) (FUJII et al., 2001) and northeast (35.9\%) (GONDIM et al., 2007).

Because of the lack of studies on bubaline toxoplasmosis and neosporosis in the state of Paraiba, the present study aimed to determine the frequency of anti- $T$. gondii and anti- $N$. caninum antibodies in buffaloes in Paraiba, as well as to identify the risk factors associated with seropositivity.

\section{Materials and Methods}

\section{Sampling}

This study was carried out on 14 farmed buffalo herds in the counties of Alagoa Nova, Areia, Campina Grande, Guarabira, Juripiranga, Santa Helena, Sapé, Rio Tinto, Santana dos Garrotes, Itatuba, Solânea and Cacimbas (Figure 1). The study population was formed of bubaline females with an aptitude for meat and milk, of mixed breed and Murrah breed, with ages $\geq 24$ months. To calculate the number of animals to be sampled, the formula (Equation 1) for simple random sampling (THRUSFIELD, 2007) was used:

$$
n=\frac{Z^{2} P(1-P)}{d^{2}}
$$

where:

$\mathrm{n}=$ number of animals to be sampled

$\mathrm{Z}=$ normal distribution value for the $95 \%$ confidence level

$\mathrm{P}=$ expected prevalence of $50 \%$ (for maximization of the sample) $\mathrm{d}=$ error of $10 \%$

In total, 136 bubaline females with ages $\geq 24$ months were selected from these 14 herds. Blood samples were collected between November 2012 and July 2013, by puncturing the jugular vein, using a disposable needle and a vacuum tube (without anticoagulant) with capacity for $15 \mathrm{ml}$. At the time of the blood collection, an epidemiological questionnaire was applied in order to obtain data for use in the risk factor analysis. The variables and respective categories used were as follows: management system (intensive, semi-intensive or extensive); type of exploitation (meat, milk or mixed); type of milking (manual or mechanical); number of
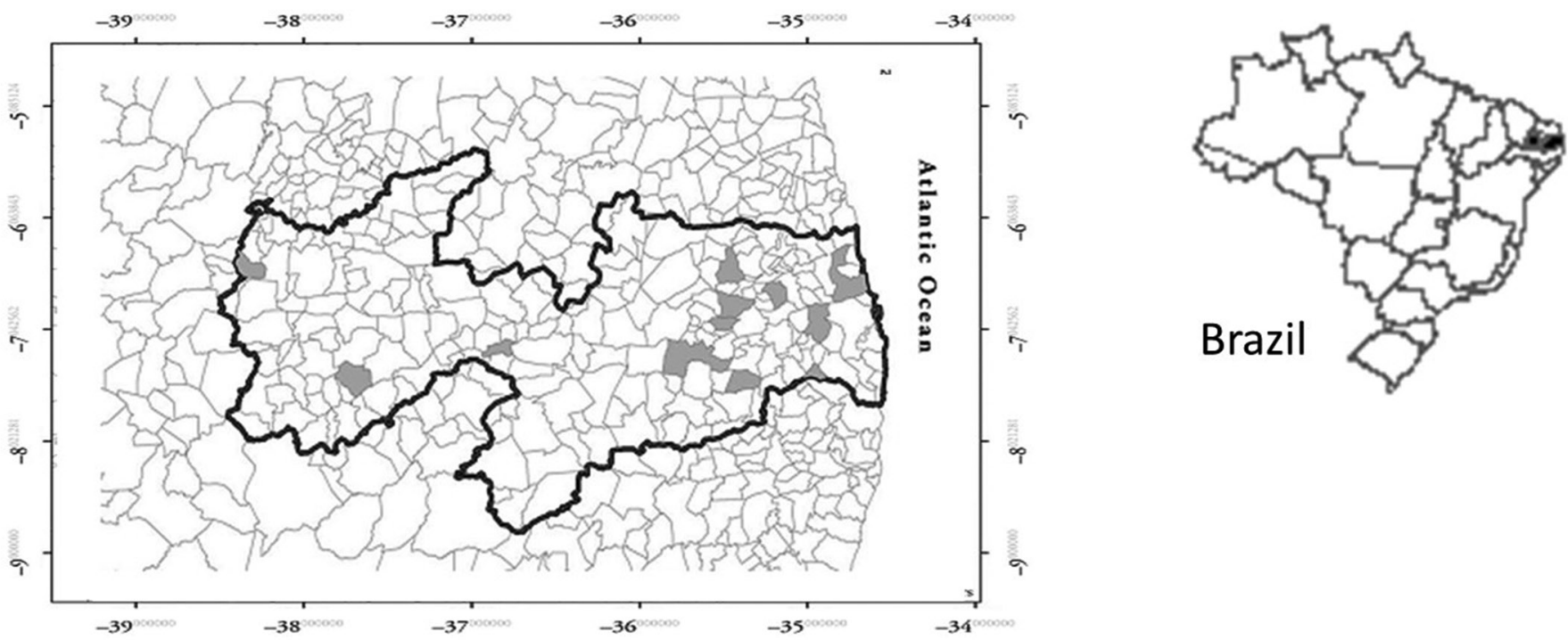

Figure 1. Geographical distribution of counties used. Detail shows the State of Paraíba - Brazil. 
milkings per day (none, once a day or twice a day); presence of other animal species (cattle, horses, goats/sheep, pigs, poultry, dogs or cats); presence of wildlife (yes or no); occurrences of miscarriages during the last 12 months (yes or no); presence of rodents (yes or no); use of rodent control (yes or no); feeding on native pasture (yes or no); water source (drinking troughs or watering points); animal purchases (yes or no); pasture rental (yes or no); presence of flooded areas (yes or no), presence of maternity pens (yes or no); separation of young from adult animals (yes or no); and presence of veterinary assistance (yes or no).

\section{Serological diagnosis}

To detect anti-T. gondii and anti- $N$. caninum antibodies, the indirect fluorescent antibody test (IFAT) was performed at the Laboratory of Parasitic Diseases, Federal University of Campina Grande, Patos, PB, Brazil. For T. gondii, the technique was carried out in accordance with the methodology described by Camargo (1974), using tachyzoites of the RH strain as antigens and a cutoff point of 1:64 (SILVA et al., 2010). For $N$. caninum, the cutoff point was 1:200 (GONDIM et al., 2007; SILVA et al., 2010) and the technique was carried out in accordance with Paré et al. (1995), using an NC-1 sample of $N$. caninum cultured in bovine monocytes as the antigen.

\section{Statistical analysis}

Risk factor analysis was performed in two steps: univariable and multivariable analysis. Univariable analysis was performed using the chi-square test or Fisher's exact test, and variables that presented $P \leq 0.20$ were used for multivariable logistic regression. The multivariable analysis was then performed, using the stepwise forward method (HOSMER \& LEMESHOW, 2000). Collinearity between independent variables was verified by a correlation analysis; for those variables with a strong collinearity (correlation coefficient $>0.9$ ), one of the two variables was excluded from the multiple analysis according to the biological plausibility (DOHOO et al., 1997). The significance level in the multivariable analysis was 5\%, and the SPSS 20.0 software for Windows was used.

\section{Results and Discussion}

Among the 136 animals, 17 (12.5\%) were seropositive for T. gondii, and the titers and respective frequencies were $64(29.4 \%)$, 128 (29.4\%), 256 (17.6\%), 512 (11.8\%) and 1,024 (11.8\%). For $N$. caninum, 26 (19.1\%) of the 136 animals were seropositive, with titers of $200(19.2 \%), 400$ (34.6\%), $800(30.7 \%)$ and 1,600 (15.3\%). Animals seropositive for both T. gondii and $N$. caninum were found in 10 of the 14 herds (71.4\%).

Tables 1 and 2 show the variables associated with seropositivity for $T$. gondii and $N$. caninum $(P \leq 0.2)$, from the univariable analysis. In the final logistic regression model (Table 3 ), the semi-intensive management system was identified as a risk factor for toxoplasmosis (odds ratio $=2.99$ ) and the presence of pigs was a risk factor for neosporosis (odds ratio $=4.33$ ).

It is known that buffaloes are considerably resistant to $T$. gondii infection (DUBEY, 1988). However, surveys carried out in Brazil such as those of Souza et al. (2001) and Silva et al. (2013), in which the frequencies of antibodies were $49.9 \%$ and $36 \%$, respectively, have suggested that there is a need for further studies on this parasitosis in buffaloes. In the present survey, the presence of antibodies was indicative of $T$. gondii circulation in buffalo herds in the state of Paraíba. This is a public health concern, given that in Brazil there has been an increase in the consumption of raw or undercooked beef, especially in areas with no federal inspection service (GUERRA et al., 2014).

The frequency of seropositivity for $N$. caninum among these buffaloes in the state of Paraíba was $19.1 \%$, and serological surveys for $N$. caninum in buffaloes in Brazil have shown frequencies ranging from $40.9 \%$ (SILVA et al., 2010) to $49.9 \%$ (SOUZA et al., 2001). In cattle, neosporosis is considered to be the greatest cause of abortions, but its impact on buffaloes' reproductive sphere remains unclear. Given that there have been

Table 1. Results from the univariable analysis, showing the variables most associated $(\mathrm{P} \leq 0.2)$ with seropositivity for $T$. gondii in buffaloes, between November 2012 and July 2013, in the state of Paraiba, Brazil.

\begin{tabular}{|c|c|c|c|c|}
\hline Variable & Category & Total number of animals & Number of positive animals (\%) & $P$ \\
\hline \multirow[t]{2}{*}{ Management system } & Semi-intensive & 32 & $7(21.9)$ & \\
\hline & Extensive & 104 & $10(9.6)$ & 0.122 \\
\hline \multirow[t]{3}{*}{ Production system } & Beef & 97 & $11(11.3)$ & \\
\hline & Dairy & 20 & $5(25)$ & 0.143 \\
\hline & & 19 & $1(5,3 \%)$ & \\
\hline \multirow[t]{2}{*}{ Presence of pigs } & No & 121 & $13(10.7)$ & \\
\hline & Yes & 15 & $4(26.7)$ & 0.179 \\
\hline \multirow[t]{2}{*}{ Use of rodent control } & No & 48 & $9(18.8)$ & \\
\hline & Yes & 88 & $8(9.1)$ & 0.175 \\
\hline \multirow[t]{2}{*}{ Access to watering points } & No & 58 & $4(6.9)$ & \\
\hline & Yes & 78 & $13(16.7)$ & 0.149 \\
\hline \multirow[t]{2}{*}{ Abortions during the last 12 months } & No & 109 & $11(10.1)$ & \\
\hline & Yes & 27 & $6(22.2)$ & 0.106 \\
\hline
\end{tabular}


Table 2. Results from the univariable analysis, showing the variables most associated $(\mathrm{P} \leq 0.2)$ with seropositivity for $N$. caninum in buffaloes, between November 2012 and July 2013, in the state of Paraiba, Brazil.

\begin{tabular}{|c|c|c|c|c|}
\hline Variable & Category & Total number of animals & Number of positive animals (\%) & $P$ \\
\hline Management system & Semi-intensive & 32 & $11(34.4)$ & \\
\hline \multirow{4}{*}{ Production system } & Extensive & 104 & $15(14.4)$ & 0.024 \\
\hline & Beef & 97 & $14(14.4)$ & \\
\hline & Dairy & 20 & $8(40)$ & 0.029 \\
\hline & & 19 & $4(21,1)$ & \\
\hline \multirow[t]{2}{*}{ Presence of pigs } & No & 121 & $18(14.4)$ & \\
\hline & Yes & 15 & $8(53,3)$ & 0.001 \\
\hline \multirow[t]{2}{*}{ Presence of goats and sheep } & No & 85 & $21(24.7)$ & \\
\hline & Yes & 51 & $5(9.8)$ & 0.056 \\
\hline \multirow[t]{2}{*}{ Animal purchases } & No & 84 & $11(13.1)$ & \\
\hline & Yes & 52 & $15(28.8)$ & 0.041 \\
\hline \multirow[t]{2}{*}{ Milk cooling } & No & 126 & $20(15.9)$ & \\
\hline & Yes & 10 & $6(60)$ & 0.003 \\
\hline
\end{tabular}

Table 3. Risk factors for T. gondii and N. caninum seropositivity among buffaloes, between November 2012 and July 2013, in the state of Paraiba, Brazil.

\begin{tabular}{lccc}
\hline \multicolumn{1}{c}{ Risk factor } & Odds ratio & 95\% CI & $\boldsymbol{P}$ \\
\hline $\begin{array}{l}\text { Toxoplasma gondii } \\
\text { Semi-intensive management } \\
\text { system }\end{array}$ & 2.99 & {$[0.99-8.98]$} & 0.050 \\
$\begin{array}{l}\text { Neospora caninum } \\
\text { Presence of pigs }\end{array}$ & & & \\
\hline
\end{tabular}

reports of isolation of $N$. caninum in buffalo brains and fetuses in Brazil (RODRIGUES et al., 2004; CHRYSSAFIDIS et al., 2011), neosporosis needs to be investigated as a possible cause of abortions in this species.

It is believed that the low frequency of seropositive animals for both $T$. gondii and $N$. caninum compared with other surveys conducted in Brazil could be explained by the low occurrence of definitive hosts in the herds since in $60 \%$ of the positive herds for T. gondii there wasn't report of cats, and in $40 \%$ of the positive herds for $N$. caninum the presence of dogs was not reported (data not shown).

Surveys on risk factors for toxoplasmosis among buffaloes are scarce in Brazil. In the present work, the semi-intensive management system was identified as a risk factor, as also found by Albuquerque et al. (2011) for cattle. This can be explained by the greater chances of contact with oocysts in the environment when this system is used, probably due to the fact that such contacts are favored both in the confinement and in the extensive management system. In the semi-intensive system, the animals remain part of the day free in pastures and part of the day confined, and are thus exposed to both environments.

The presence of pigs was identified as a risk factor for occurrences of anti- $N$ caninum antibodies in buffaloes in the state of Paraíba. Even though the presence of pigs does not has direct importance with regard to transmission of this agent to buffaloes, Azevedo et al (2010) reported findings of pigs positive for $N$ caninum in Paraiba, using IFAT and immunoblotting with total and purified antigen (p38 - NcSRS2) of $N$. caninum tachyzoites. This suggests that complementarity of life cycles in the herds may exist when definite hosts are present. Therefore, studies aiming to isolate the agent in pigs and buffaloes are necessary in order to elucidate the real importance of neosporosis in these species.

The frequencies of buffaloes seropositive for $T$. gondii and $N$. caninum in the state of Paraíba, northeastern Brazil suggest that both of these agents are spreading in this region. From our risk factor analysis, it is suggested that further surveys on the importance of these agents in this species and in pigs are needed, as well as evaluation of the influence of the type of management system on occurrences of seropositive animals.

\section{References}

Albuquerque GR, Munhoz AD, Teixeira M, Flausino W, Medeiros SM, Lopes CWG. Risk factors associated with Toxoplasma gondii infection in dairy cattle, state of Rio de Janeiro. Pesqui Vet Bras 2011; 31(4): 287-290. http://dx.doi.org/10.1590/S0100-736X2011000400003.

Azevedo SS, Pena HFJ, Alves CJ, Guimarães AAM Fo, Oliveira RM, Maksimov P, et al. Prevalence of anti-Toxoplasma gondii and anti-Neospora caninum antibodies in swine from Northeastern Brazil. Rev Bras Parasitol Vet 2010; 19(2): 80-84. http://dx.doi.org/10.4322/rbpv.01902002. PMid:20624342.

Camargo ME. Introdução das técnicas de imunofluorescência. Rev Bras Patol Clin 1974; 10(3): 87-107.

Chryssafidis AL, Soares RM, Rodrigues AAR, Carvalho NAT, Gennari SM. Evidence of congenital transmission of Neospora caninum in naturally infected water buffalo (Bubalus bubalis) fetus from Brazil. Parasitol Res 2011; 108(3): 741-743. http://dx.doi.org/10.1007/s00436-010-2214-2. PMid:21181191. 
Dohoo IR, Ducrot C, Fourichon C, Donald A, Hurnik D. An overview of techniques for dealing with large numbers of independent variables in epidemiologic studies. Prev Vet Med 1997; 29(3): 221-239. http://dx.doi. org/10.1016/S0167-5877(96)01074-4. PMid:9234406.

Dubey JP, Hattel AL, Lindsay DS, Topper MJ. Neonatal Neospora caninum infection in dogs: isolation of the causative agent and experimental transmission. J Am Vet Med Assoc 1988; 193(10): 1259-1263. PMid:3144521.

Dubey JP. Long-term persistence of Toxoplasma gondii in tissues of pigs inoculated with $T$. gondii oocysts and effect of freezing on viability of tissue cysts in pork. Am J Vet Res 1988; 49(6): 910-913. PMid:3400928.

Dubey JP. Review of Neospora caninum and neosporosis in animals. Korean J Parasitol 2003; 41(1): 1-16. http://dx.doi.org/10.3347/kjp.2003.41.1.1. PMid:12666725.

Fujii TU, Kasai N, Nishi SM, Dubey JP, Gennari SM. Seroprevalence of Neospora caninum in female water buffaloes (Bubalus bubalis) from the southeastern region of Brazil. Vet Parasitol 2001; 99(4): 331-334. http://dx.doi.org/10.1016/S0304-4017(01)00474-5. PMid:11511420.

Gondim LFP, Pinheiro AM, Almeida MAO. Frequência de anticorpos anti-Neospora caninum em búfalos (Bubalus bubalis) criados no estado da Bahia. Rev Bras Saúde Prod Anim 2007; 8(2): 92-96.

Guerra NR, Alves BHLS, Farias MPO, Mota RA, Alves LC. Frequency of Toxoplasma gondii antibodies in bovines in the state of Pernambuco, Brazil. Rev Bras Parasitol Vet 2014; 23(3): 417-419. http://dx.doi.org/10.1590/ S1984-29612014056. PMid:25271467.

Hosmer DW, Lemeshow S. Applied logistic regression. 2nd ed. New York: John Wiley \& Sons; 2000.

Instituto Brasileiro e Geografia e Estatística - IBGE. Sistema IBGE de Recuperação Automática - SIDRA [online]. Rio de Janeiro: IBGE; 2012 [cited 2013 Dec 11]. Available from: http://www.sidra.ibge.gov.br/bda/

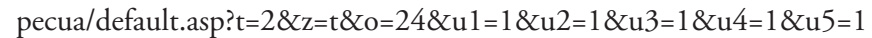
$\& \mathrm{u} 6=1 \& \mathrm{u} 7=1$.

Nardi G Jr. Perfil sorológico de anticorpos anti-Leptospira spp. em búfalas (Bubalus bubalis) vacinadas com dois tipos de vacinas comerciais antileptospirose (bacterina e membrana externa) [Dissertação]. São Paulo: Universidade de São Paulo; 2005.

Paré J, Hietala SK, Thurmond MC. An enzyme-linked immunosorbent assay (ELISA) for serological diagnosis of Neospora sp. infection in cattle. J Vet Diagn Invest 1995; 7(3): 352-359. http://dx.doi. org/10.1177/104063879500700310. PMid:7578451.

Rodrigues AAR, Gennari SM, Aguiar DM, Sreekumar C, Hill DE, Miska $\mathrm{KB}$, et al. Shedding of Neospora caninum oocysts by dogs fed tissues from naturally infected water buffaloes (Bubalus bubalis) from Brazil. Vet Parasitol 2004; 124(3-4): 139-150. http://dx.doi.org/10.1016/j. vetpar.2004.07.007. PMid:15381294.

Silva JB, Fonseca AH, Andrade SJT, Silva AGM, Oliveira CMC, Barbosa JD. Prevalência de anticorpos anti-Toxoplasma gondii em búfalos (Bubalus bubalis) no Estado do Pará. Pesqui Vet Bras 2013; 33(5): 581-585. http:// dx.doi.org/10.1590/S0100-736X2013000500005.

Silva SP, Mota RA, Faria EB, Fernandes ETFS, Neto OLS, Albuquerque PPF, et al. Anticorpos IgG anti-Neospora caninum e Toxoplasma gondii em búfalas (Bubalus bubalis) criadas no estado do Pará. Pesqui Vet Bras 2010; 30(5): 443-446. http://dx.doi.org/10.1590/S0100-736X2010000500012.

Souza LM, Nascimento AA, Furuta PI, Basso LMS, Silveira DM, Costa AJ. Detecçáo de anticorpos contra Neospora caninum e Toxoplasma gondii em soros de bubalinos (Bubalus bubalis) no Estado de São Paulo, Brasil. Semina Cienc Agrar 2001; 22(1): 39-48. http://dx.doi.org/10.5433/16790359.2001v22n1p39.

Thrusfield M. Veterinary epidemiology. 3rd ed. Oxford: Blackwell Science; 2007. 